\title{
The Analysis of Factors Affecting Dividend Policy in Food and Beverage Sector Manufacturing Companies Listed in Indonesia Stock Exchange in 2015-2017
}

\author{
Nia Angelia ${ }^{1}$, Nagian Toni ${ }^{2}$ \\ ${ }^{1}$ Master of Management, Universitas Prima Indonesia, Indonesia \\ ${ }^{2}$ LectuUniversitas Prima Indonesia, Indonesia
}

\begin{abstract}
:
Dividend policy is one of the policies in the company that must be considered and considered carefully. The dividend policy determines the amount of profit allocation that can be distributed to shareholders (dividends) and the profit allocation that a company can hold. The greater the retained earnings, the smaller the profits that will be distributed to shareholders. In the allocation of profits, various kinds of problems are encountered. Dividends are considered as a way to reduce the problems that arise between management and shareholders by giving the rights of shareholders. There are several factors that influence dividend policy, but researchers only examine three variables, namely liquidity, profitability and leverage. This study aims to examine the effect of variable liquidity, profitability and leverage on dividend policy both partially and simultaneously. The sample of this study is the food and beverage sector manufacturing companies listed on the Indonesia Stock Exchange in 2015-2017 with a total of 25 companies using a purposive sampling method obtained as many as 18 sample companies. The analytical method used is the classic assumption test and hypothesis testing and multiple linear analyses. The results showed that simultaneously all independent variables influence dividend policy. Profitability partially affects dividend policy while liquidity and leases partially do not affect dividend policy. The adjusted $R$ square value of 0.382 indicates the dependent variable (Dividend Payout Ratio) can be explained by the independent variables (liquidity, profitability and leverage) of $38.2 \%$.
\end{abstract}

\section{Keywords}

Liquidity; profitability; leverage and dividend policy

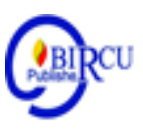

\section{Introduction}

In the current economic development, manufacturing companies are required to be able to compete in the industrial world. Manufacturing companies need to invest to increase the company's business capital. To invest, various kinds of information about the issuer are needed, both company performance information in the form of financial statements or other relevant information. The economic development of a country can be measured in many ways, one of which is by knowing the level of world capital market development. The capital market is a place for investors to conduct investment activities. Investors in investing funds into a company will be faced with return on investment in the form of dividends and capital 
gains. Capital gains are capital gains derived from the difference between the purchase price and the selling price of the shares, while the dividends are the portion of net income distributed by the company to shareholders.

Dividend policy deals with the distribution of income (earnings) between the use of income paid as dividends for shareholders or used as retained earnings within a company. This decision was made as a way to improve the welfare of shareholders, (Bella Novianti Rais and Hendra F. Santoso, 2017: 112).

In anthropological studies, artifacts are a form of physical culture in the form of the If the company's liquidity position is strong, the company's ability to pay dividends is large, given that dividends are cash outflows for the company. Company liquidity is shown by the size of current assets, which are assets that are easy to be converted into cash which includes cash, securities, receivables and inventories, (Agus Sartono, 2010: 116).

Profitability is the ratio used to measure a company's ability to generate profits with the company's resources. Companies that have stability in obtaining profits can give signals to the public about the ability to pay dividends, (Hery, 2013).

Leverage shows the extent to which a company fulfills all its obligations through debt. The higher the leveragemaka, the higher the risk faced by the company and the higher the expected rate of return. Leverage is a description of the extent to which a company's assets are financed with debt and how much debt burden is borne by the company compared to its assets, (Kasmir, 2010: 112)

Therefore the previous study about affecting had written by Factors Romdony (2019) with entitled Affecting Customer Loyalty in Product. The result shows that customer loyalty can be formed from the commitment of the management of business organizations to provide the best for consumers, especially related to product quality, competitive prices, and satisfying services. However, several obstacles faced by business organizations include high raw materials, and capital. Therefore, the role of the government is highly expected by business actors, especially related to the import policy of raw materials which is considered very burdensome to producers.

\subsection{The Problem of Study}

Based on the background that has been stated, the problems in this study are:

1. Does liquidity affect dividend policy in the food and beverage sector manufacturing companies listed on the Indonesia Stock Exchange in 2015-2017.

2. Does profitability affect dividend policy in food and beverage sector manufacturing companies listed on the Indonesia Stock Exchange in 2015-2017.

3. Does leverage affect dividend policy on food and beverage manufacturing companies listed on the Indonesia Stock Exchange in 2015-2017.

4. Does liquidity, profitability and leverage simultaneously affect the dividend policy in the food and beverage sector manufacturing companies listed on the Indonesia Stock Exchange in 2015-2017.

\subsection{The Purposes of Study}

In accordance with the formulation of the problem that has been previously formulated, the purpose of this study is to analyze and test:

1. The effect of liquidity on dividend policy on food and beverage manufacturing companies listed on the Indonesia Stock Exchange in 2015-2017. 
2. The effect of profitability on dividend policy on food and beverage manufacturing companies listed on the Indonesia Stock Exchange in 2015-2017.

3. The influence of leverage on dividend policy on food and beverage sector manufacturing companies listed on the Indonesia Stock Exchange in 2015-2017.

4. Simultaneous influence of liquidity, profitability and leverage on dividend policy in the food and beverage sector manufacturing companies listed on the Indonesia Stock Exchange in 2015-2017.

\section{Research Method}

\subsection{Effect of Liquidity on Dividend Policy}

Liquidity is the company's ability to pay its obligations which must be fulfilled immediately. The obligation that must be fulfilled immediately is short-term debt, therefore this ratio can be used to measure the level of security of short-term creditors, and to measure whether the company's operations will not be disrupted if these short-term obligations are immediately billed, (Sutrisno, 2012: 15).

The company's liquidity position is a factor influencing dividend policy. Cash Dividend is a cash outflow for the company, therefore if the company pays a dividend means it must provide enough cash, and will reduce the level of company liquidity. For companies with poor liquidity conditions, they usually tend to pay cash dividends in small amounts, because most of the profits are used to increase liquidity. But established companies with good liquidity tend to distribute larger dividends to shareholders, (Sutrisno, 2012: 267).

\subsection{Effect of Profitability on Dividend Policy}

Profitability is the company's ability to make a profit in relation to sales, total assets and own capital. Profitability ratios are very important to know by users of financial statements because they inform how much the company's ability to generate profits, the greater the profit ratio shows the better management in managing the company, (Sartono, 2010: 122).

For companies whose income is stable, the dividend to be paid to shareholders is greater than for companies whose income is unstable. Companies whose income is unstable do not need to provide a lot of cash just in case, while companies with stable income must provide cash that is large enough to be on guard, (Sutrisno, 2012: 267).

\subsection{Effect of Leverage on Dividend Policy}

According to Brigham and Houston (2011), stating the use of large amounts of debt will increase company risk, which increases the cost of debt.

According to Fahmi (2012), concluding that the higher the leverage ratio shows the greater the use of debt which results in the greater financial risk faced by the company.

\subsection{Conceptual Framework}

To illustrate how the course of research logically and scientifically, a schematic framework of thought is formed. The conceptual framework is made in such a way that it is easy to understand and can be described as follows: 


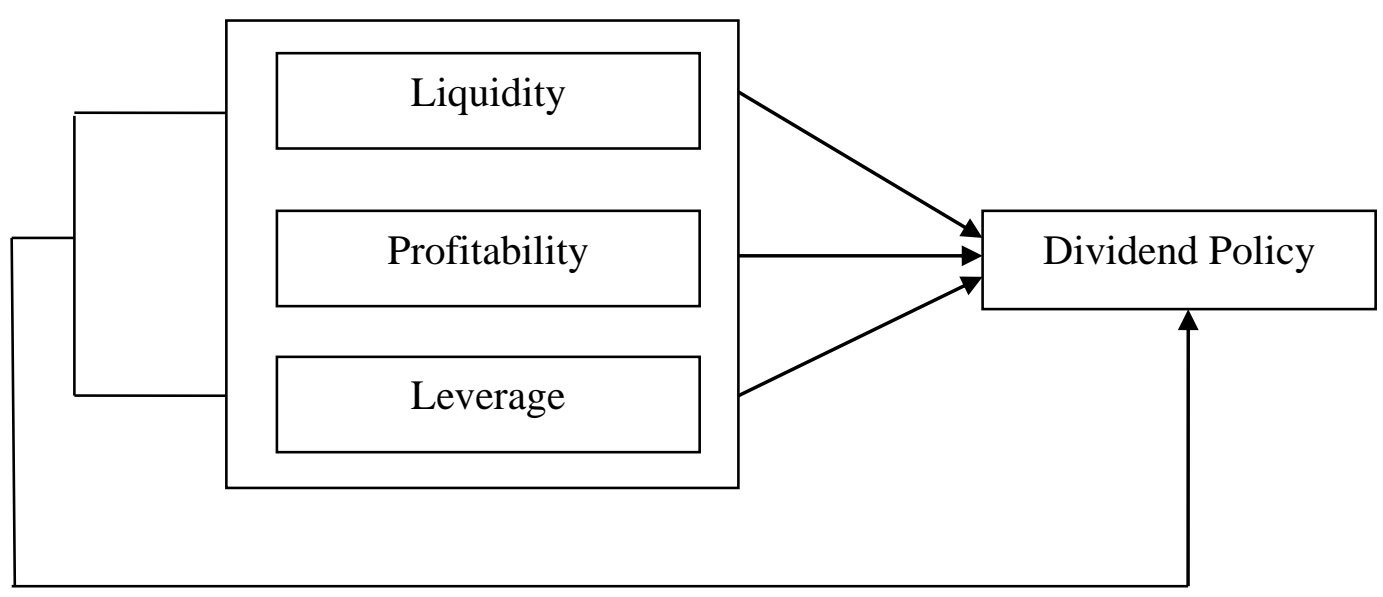

Figure 1. Conceptual framework

\subsection{Research Hypothesis}

Based on the conceptual framework above, hypotheses can be formulated as follows:

1: Liquidity affects dividend policy in the food and beverage manufacturing companies listed in the Indonesia Stock Exchange in 2015-2017.

2: Profitability has an effect on dividend policy on food and beverage manufacturing companies listed on the Indonesia Stock Exchange in 2015-2017.

3: Leverage affects the dividend policy of the food and beverage sector manufacturing companies listed on the Indonesia Stock Exchange in 2015-2017.

4: Liquidity, profitability and leverage affect the dividend policy of food and beverage manufacturing companies listed on the Indonesia Stock Exchange in 2015-2017.

\section{Research Method}

This research was conducted at the food and beverage sector manufacturing companies listed on the Indonesia Stock Exchange in 2015-2017 through the official website www.idx.co.id.

In this study, the type of data used is secondary data that is research data obtained indirectly through intermediary media. Secondary data in this study were obtained from the Indonesia Stock Exchange website, www.idx.co.id.

Data collection technique is the documentation where the technique of collecting data on historical events written in documents or in the form of electronic data archives. The data collected is data relating to the object being studied obtained from the Indonesian Stock Exchange (IDX). Researchers can also add and conduct documentation studies by reviewing and deepening the literature, such as books, journals, and research reports related to the problem under study.

The sampling technique in this study uses the Purpose Sampling method, which is a sampling technique with certain considerations (Sugiyono, 2012: 118).

In this study, the criteria set are as follows:

1. Food and beverage manufacturing sector companies listed on the Indonesia Stock Exchange in 2015-2017.

2. Companies that experienced profits in 2015-2017.

3. Companies that distribute dividends in 2015-2017. 
Table 1. Sample Selection Criteria

\begin{tabular}{|l|l|c|}
\hline No & \multicolumn{1}{|c|}{ Sample Selection Criteria } & Total \\
\hline 1. & $\begin{array}{l}\text { Food and beverage sector manufacturing } \\
\text { companies listed on the Indonesia Stock Exchange } \\
\text { in 2015-2017 }\end{array}$ & 25 \\
\hline 2. & Companies that suffered losses in 2015-2017 & $(1)$ \\
\hline 3. & $\begin{array}{l}\text { Companies that do not distribute in 2015-2017 } \\
\text { The number of companies selected as research } \\
\text { samples }\end{array}$ & 18 \\
\hline
\end{tabular}

Source: www.idx.co.id

From the results of the above criteria, the companies that met the criteria to be sampled were 18 companies. The total number of samples to be studied was 54 observations (18x3).

\section{Results and Discussion}

\subsection{Results of Multiple Linear Regression Analysis}

Based on the results obtained by the multiple linear regression equation the research hypothesis is as follows: DPR $=-0.007+(-0.418 \mathrm{CR})+0.355 \mathrm{ROA}+(-0.4472 \mathrm{DER})$.

From the multiple linear equation of the research hypothesis, the following information is obtained:

1. The constant value (a) is -0.007 meaning that if the independent variable namely Current Ratio, Return On Assets and Debt to Equity Ratio is considered constant, then the value of Dividend Payout Ratios in the Food and Beverage sector manufacturing companies listed on the Indonesia Stock Exchange is -0.007 .

2. The Current Ratio (X1) regression coefficient is -0.418 . This shows that every one time increase in Current Ratio will be followed by a decrease in Dividend Payout Ratio of -0.418 .

3. The Return On Asset (X2) regression coefficient is 0.355. This shows that each increase in Return on Assets once will be followed by an increase in Dividend Payout Ratios of 0.3554 .

4. Regression coefficient Debt to Equity Ratio (X3) is -0.472 . This shows that each increase in Debt to Equity Ratio once will be followed by a decrease in Dividend Payout Ratio of -0.472 .

\subsection{Simultaneous Hypothesis Testing (Statistical Test F)}

Simultaneous hypothesis testing (F-Test) is used to find out how far the influence of the independent variables on the dependent variable simultaneously or as a whole. The test results with the F-Test are as follows:

Table 2. Statistical Test Results F

\begin{tabular}{|ll|c|c|c|c|c|}
\hline & Model & $\begin{array}{c}\text { Sum of } \\
\text { Squares }\end{array}$ & df & Mean Square & F & Sig. \\
\hline 1 & Regression & 9,666 & 3 & 3,222 & 11,924 &, $000 \mathrm{~b}$ \\
& Residual & 13,511 & 50 &, 270 & & \\
& Total & 23,176 & 53 & & & \\
\hline
\end{tabular}

Source: SPSS Data Processing Results

From Table 2 above, we can see the result of $F_{\text {count }}$ is 11.924 while $F_{\text {table }}$ is 2.79 (attachment) then the conclusion is $F_{\text {count }}>F_{\text {table }}(11.924>2.79)$ with a significant value of 
$0.000<0.05$ then $\mathrm{H} 0$ is rejected and $\mathrm{Ha}$ is accepted which means Current Ratio, Return On Asset and Debt to Equity Ratio variables simultaneously have a significant effect on Dividend Payout Ratios in Food and Beverage manufacturing companies in the Indonesia Stock Exchange in 2015-2017.

\subsection{Partial Hypothesis Testing (Statistical Test $\mathrm{t}$ )}

Partial hypothesis testing (t-test) is used to find out how far the influence of the independent variables on the dependent variable partially or individually. The test results with the t-test are as follows:

Table 3. Statistical Test Results t

Coefficients

\begin{tabular}{|cl|l|l|l|l|l|}
\hline \multirow{2}{*}{ Model } & \multicolumn{2}{|l|}{$\begin{array}{l}\text { Unstandardized } \\
\text { Coefficients }\end{array}$} & $\begin{array}{l}\text { Standardized } \\
\text { Coefficients }\end{array}$ & \multirow{2}{*}{ Sig. } \\
\cline { 3 - 5 } & B & $\begin{array}{l}\text { Std. } \\
\text { Error }\end{array}$ & Beta & \\
\hline \multirow{2}{*}{1} & (Constant) &,- 007 &, 241 & &,- 027 &, 978 \\
& LN_X1 &,- 418 &, 122 &,- 545 & $-3,415$ &, 001 \\
& LN_X2 &, 355 &, 107 &, 371 & 3,323 &, 002 \\
& LN_X3 &,- 472 &, 121 &,- 619 & $-3,901$ &, 000 \\
& & & & & \\
\hline
\end{tabular}

Source: SPSS Data Processing Results

The partial statistical test results are as follows:

1. Current Variable variable has a significant value of $0.001<0.05$ and the result of $t_{\text {count }}$ $<t_{\text {table }}(-3.415<1.99547)$ then $\mathrm{H} 0$ is rejected Ha which means that the Current Ratio variable partially has a negative and significant effect on Dividend Payout Ratio in Food and Manufacturing sector companies Beveragedi Indonesia Stock Exchange in 2015-2017.

2. Return On Assets Variable has a significant value of $0.002<0.05$ and the result of $t_{\text {count }}>t_{\text {table }}(3.323>1.99547)$ then HO is rejected Ha which means that the Return On Asset variable partially has a positive and significant effect on the Dividend Payout Ratios in the manufacturing companies in the Food and Food sector Beveragedi Indonesia Stock Exchange in 2015-2017.

3. Variable Debt to Equity Ratios have a significant value of $0,000<0.05$ and the results of $\mathrm{t}_{\text {count }}<\mathrm{t}_{\text {table }}(-3.901<1.99547)$ then $\mathrm{H} 0$ is rejected Ha is accepted, which means that the variable Debt to Equity Ratios partially has a negative and significant effect on Dividend Payout Ratios on the company the Food and Beverage manufacturing sector on the Indonesia Stock Exchange in 2015-2017.

\subsection{Current Research Results on Dividend Payout Ratio}

Based on the test results show that the liquidity variable (Current Ratio) has a negative and significant effect on the dividend policy (Dividend Payout Ratio) in the food and beverage manufacturing sector of the Indonesia Stock Exchange in 2015-2017, so it can be concluded that the liquidity conditions within the company are quite good. This shows that the higher the level of liquidity, the lower the dividend policy. Vice versa, the lower the level of liquidity, the higher the distribution of dividends to the company. 
Liquidity is measured by distributing current assets with current debt, so every transaction made by a company that results in changes in the number of current assets with current debt will affect the Current Ratio, which means that it results in changes in the level of company liquidity. The company's liquidity position is a factor influencing dividend policy. If the company pays dividends, then the company must provide enough cash. The high value of Current Ratio shows investors' confidence in the company's ability to pay the promised dividends. This research proves that liquidity has an influence on dividend policy in the Food and Beverage manufacturing companies in the Indonesia Stock Exchange in 20152017.

\subsection{Research Results Return on Assets Against Dividend Payout Ratio}

The results of the analysis state that profitability (Return On Assets) has an influence on dividend policy (Dividend Payout Ratio) in the food and beverage manufacturing sector of the Indonesia Stock Exchange in 2015-2017 which gives an indication that the company is able to generate profits. For companies whose income is stable, the dividend to be paid to shareholders is greater than for companies whose income is unstable. This is due to the increased ability of companies to generate profits which will certainly increase the distribution of dividends and provide a good signal for investors about the company's ability to generate profits. Indonesia in 2015-2017.

\subsection{Debt to Equity Ratio Research Results on Dividend Payout Ratio}

The results of hypothesis testing concluded that leverage (DER) had a significant influence on dividend policy (DPR) in the food and beverage manufacturing sector of the Indonesia Stock Exchange in 2015-2017. In developing the company, the company needs additional capital that not only comes from internal funds (retained earnings), but also requires external funds (debt). This long-established and stable company has won the trust of creditors in lending funds. The funds are used as additional capital to carry out operational activities and invest in order to get a greater profit than before using debt. In this case the company has the ability to manage finances so that with a high level of debt can pay obligations and can also pay dividends. Increasing the use of debt will reduce dividend payments because the company has a high fixed burden so that it will reduce the company's net profit, declining net income will have an impact on dividend payments. So the higher the level of leverage, the lower the ability to distribute dividends and vice versa if the level of leverage is low, the company's ability to distribute dividends will be high. This research proves that leverage has an influence on dividend policy in the Food and Beverage manufacturing companies in the Indonesia Stock Exchange in 2015-2017.

\subsection{Current Research Ratio, Return On Asset And Debt to Equity Ratio Against Dividend Payout Ratio}

Partial test results show different effects, but if combined (simultaneously) variable liquidity (CR), profitability (ROA) and leverage (DER) have a significant effect on dividend policy (DPR) in food and beverage manufacturing companies in the Stock Exchange Indonesia in 2015-2017, and this regression model is able to explain variations in changes in the variable dividend policy (DPR) by $38.2 \%$ while the remaining $61.8 \%$ is influenced by other factors not examined. This shows that the determination of dividend payments is not only influenced by fundamental factors of the company, it is also likely to be influenced by global economic factors that occurred in 2015-2017. This research proves that liquidity, profitability and leverage simultaneously influence dividend policy 


\section{Conclusion}

Based on the results of research conducted by researchers, the following conclusions are obtained:

1. Liquidity partially influences the dividend policy of the Food and Beverage manufacturing companies in the Indonesia Stock Exchange in 2015-2017.

2. Profitability partially influences dividend policy in the Food and Beverage manufacturing sector companies on the Indonesia Stock Exchange in 2015-2017.

3. Leverage partially affects dividend policy in the Food and Beverage manufacturing sector companies on the Indonesia Stock Exchange in 2015-2017.

4. Liquidity, profitability, and leverage have a simultaneous effect on the value of the company in the Food and Beverage manufacturing sector of the Indonesia Stock Exchange in $2015-2017$, amounting to $38.2 \%$, while the remaining $61.8 \%$ is explained by other variables.

Based on the results of research that researchers have suggested, the suggestions that researchers can provide are as follows:

1. Companies can reduce individuals in a long-term framework to avoid the issuance of new shares, so that the target long-term payment ratio allows the company to still be able to meet the needs of funds with equity from retained earnings.

2. Investors should analyze the performance and prospects of the stock first before investing in shares, namely by considering the amount of liquidity (CR), profitability (ROA) and leverage (DER) that will affect the decision making of dividends (DPR) of the issuer's company.

3. For further researchers, limitations in this study should be further refined for example by adding a number of research samples, expanding the research sample not only to focus on food and beverage and adding other variables such as exchange rates, inflation, Good Corporate Governance, investment decisions, company size, and etc.

\section{References}

Bringham, Eugene F \& Houston, Joel F. (2010). Dasar -Dasar Manajemen Keuangan. Edisi Kesebelas. Buku Pertama. Jakarta : Salemba Empat.

Edisi Kesebelas. Buku Pertama. Jakarta : Salemba Empat.

Eltya, Sandy, et.al. (2016). Pengaruh Leverage, Likuiditas, Profitabilitas dan Ukuran Perusahaan Terhadap Kebijakan Dividen (Studi Pada Perusahaan Perbankan Yag Terdaftar di Bursa Efek Indonesia Periode 2012-2014). Jurnal Adminsitrasi Bisnis (Volume 38 Nomor 2).

Fahmi, Irham. (2014).Pengantar Manajemen Keuangan. Cetakan Ketiga. Bandung : Alfabeta. Ghozali, Iman.(2013).Aplikasi Analisis Multivariate dengan Program IBM SPSS 21. Cetakan Ketujuh. Semarang :Universitas Diponegoro.

Guinan, Jack. (2010). Investopedia : Cara Mudah Memahami Istilah Investasi.Cetakan Pertama. Jakarta : Hikmah.

Gumanti, Tatang Ari.(2013). Kebijakan Dividen. Ed 1. Yogyakarta : UPP STIM YKPN.

Hanafi, Mamduh M \& Abdul Halim.2009.Analisis Laporan Keuangan. Ed 4, Yogyakarta : UPP STIM YKPM.

Harahap, Sofian Safri. (2010). Analisis Krisis Atas Laporan Keuangan. Jakarta : Rajawali Pers. 
Harahap, Sofyan Syafri. (2013). Analisis Krisis Atas Laporan Keuangan. Cetakan Kesebelas. Jakarta : Rajawali Pers.

Harmono. (2014). Manajemen Keuangan. Edisi 1. Jakarta : PT.Bumi Aksara. . (2009). Manajemen Keuangan Perusahaan. Jakarta:Bumi Aksara.

Herawati, Aty \& Firly Irradha Fauzia. (2018). The Effect of Current Ratio, Debt to Equity Ratio and Return on Asset on Dividend Payout Ratio in Sub-sector Automotive and Component Listed in Indonesia Stock Exchange in Periode 2012-2016. Internasional Conference of Organizational Innovation(Volume 2018).

Hery.(2015). Analisis Laporan Keuangan Pendekatan Rasio Keuangan. Cetakan Pertama. Yogyakarta : CAPS.

Haruman, Tendi \& Siti Komariah. (2006). Analisis Faktor-Faktor Yang Mempengaruhi Kebijakan Dividen dan Pengaruhnya Terhadap Nilai Perusahaan Pada Industri Barang Konsumsi Periode 1994-2003.Seminar Knowledge Management,KKMI ITB.

Horne, James C.Van dan John M.Wachowicz, JR. (2009). Prinsip-Prinsip Manajemen Keuangan. Jakarta: Salemba Empat.

Husnan, A \& Enny Pudjiastuti. (2006).Dasar-Dasar Manajemen Keuangan. Ed 5, Yogyakarta : UPP STIM YKPN.

UPP STIM YKPN.J.P.

Jumingan. (2008). Analisis Laporan Keuangan. Cetakan Kedua. Jakarta : PT.Bumi Aksara.

Kasmir. (2008). Bank dan Lembaga Keuangan Lainnya. Edisi Revisi. Jakarta : PT.Rajagrafindo Persada.

--------. (2010). Pengantar Manajemen Keuangan. Jakarta:Kencana Prenada Media Group.

-------. (2012). Analisis Laporan Keuangan. Cetakan Kelima. Jakarta : PT.Grafindo Persada.--------. 2014. Analisis Laporan Keuangan. Edisi 7. Jakarta : Rajawali Pers.

Keown. (2008). Manajemen Keuangan. Edisi 10. Jakarta : PT. Indeks.

Lestari, Keukeu Firda, et.al.(2016).Pengaruh Likuiditas dan Profitabilitas Terhadap Kebijakan Dividen. Journal of Business Mangement Education(Volume 1 Nomor 2).

Monika, Ni Gusti Ayu Putu Debi \& Luh Komang Sudjarni. (2018). Pengaruh Likuiditas, Profitabilitas dan LeverageTerhadap Kebijakan Dividen Pada Perusahaan Manufaktur Di Bursa Efek Indonesia. E-Jurnal Manajemen Unud (Volume 7 Nomor 2).

Nurwani.(2017).Pengaruh Likuiditas dan Profitabilitas Terhdapa Kebijakan Dividen : Studi Pada Perusahaan Manufaktur Yag Terdaftar di Bursa Efek Indonesia. Jurnal Riset Finansial Bisnis (Volume 1 Nomor 1).

Oktaviani, Lidya \& Sautma Ronni Basana.(2015).Analisa Faktor-Faktor Yang Mempengaruhi Kebijakan Dividen. Jurnal Riset Ekonomi dan Manajemen (Volume 15 Nomor 2).

Rais, Bella Novianti \& Hendra F.Santoso. (2017). Pengaruh Kepemilikan Manajerial, Kepemilikan Institusional, Profitabilitas dan Ukuran Perusahaan Terhadap Kebijakan Dividen. Jurnal Ilmiah Manajemen Bisnis (Volume 17 Nomor 2).

Sartono, Agus. (2010). Manajemen Keuangan Teori dan Aplikasi. Edisi 4, Yogyakarta : BPFE.

Sugiono, A \& Edy Untung.(2008).Panduan Praktis Dasar Analisa Laporan Keuangan. Jakarta : Grasindo.

Sugiyono. (2012). Metode Penelitian Pendidikan. Cetakan Kelimabelas Bandung : Alfabeta.

Sugiyono. (2016). Metode Penelitian Kuantitatif, Kualitatif, dan R\&D. Bandung : PT.Alfabet. 